Check for updates

Cite this: RSC Adv., 2019, 9, 38265

Received 4th October 2019

Accepted 18th November 2019

DOI: 10.1039/c9ra08051a

rsc.li/rsc-advances

\title{
Green synthesis of palladium nanoparticles using lentinan for catalytic activity and biological applications $\uparrow$
}

\author{
Zengsheng Han, ${ }^{a}$ Le Dong, ${ }^{a}$ Jin Zhang, ${ }^{\mathrm{b}}$ Tianming Cui, ${ }^{\mathrm{a}}$ Shengfu Chen, (D) ${ }^{\mathrm{c}}$ \\ Guanglong $\mathrm{Ma}^{\mathrm{c}}$ Xiaolei Guo ${ }^{\mathrm{a}}$ and Longgang Wang (D) *a
}

\begin{abstract}
The green synthesis of palladium nanoparticles (Pd NPs) for catalysis and biological applications has been gaining great interest. To replace complex plant extracts, lentinan (LNT) may be a good reducing and stabilizing agent. In this work, a simple and green method using LNT to reduce and stabilize palladium $\mathrm{Pd}$ NPs was verified. The resulting LNT stabilized palladium nanoparticles ( $\left.\mathrm{Pd}_{n}-\mathrm{LNT} N P s\right)$ were characterized by UV-Vis spectroscopy, DLS, TEM, and XPS. The results indicated that Pd NPs inside of $\mathrm{Pd}_{n}$-LNT NPs had a small size (2.35-3.32 nm). Pd $\mathrm{d}_{n}$-LNT NPs were stable in solution for 7 days. In addition, $\mathrm{Pd}_{n}-$ LNT NPs had higher catalytic activity towards the reduction of 4-nitrophenol than other catalysts. More importantly, $\mathrm{Pd}_{n}$-LNT NPs had negligible cytotoxicity towards cells and showed good antioxidant activity. Taken together, the prepared $\mathrm{Pd}_{n}$-LNT NPs have great potential bio-related applications.
\end{abstract}

\section{Introduction}

Metal nanoparticles play an increasingly important role in many areas such as catalysis, sensors, and controlled drug delivery. ${ }^{1-3}$ The various applications of metal nanoparticles are often related to their size and stability in solutions. Metal nanoparticles have been extensively prepared by using many kinds of materials. To tune their size, many agents such as sodium borohydride $\left(\mathrm{NaBH}_{4}\right)$, and dimethylamine borane (DMAB) are used to reduce metal ions to produce zerovalent metal nanoparticles. In addition, to increase their stability, many polymers such as polyvinyl pyrrolidone (PVP), and polyethyleneimine (PEI) are employed to stabilize metal nanoparticles. However, most of these chemicals are toxic and harmful to biological applications of prepared metal nanoparticles.

In order to minimize the usage of hazardous chemicals, the green methods for the preparation of biocompatible metal nanoparticles are drawing great attention. The green methods of using various plant extracts have many advantages such as eco-friendly, low cost and low energy consumption. These plant

${ }^{a}$ Key Laboratory of Applied Chemistry, College of Environmental and Chemical Engineering, Yanshan University, Qinhuangdao, 066004, China. E-mail: lgwang@ ysu.edu.cn

${ }^{b}$ College of Chemistry and Environmental Engineering, Shanxi Datong University, Datong, 037009, China

'Key Laboratory of Biomass Chemical Engineering of Ministry of Education, College of Chemical and Biological Engineering, Zhejiang University, Hangzhou, 310027, China

$\dagger$ Electronic supplementary information (ESI) available. See DOI: $10.1039 / \mathrm{c} 9 \mathrm{ra} 08051 \mathrm{a}$ extracts include turmeric extracts, ${ }^{4}$ pomegranate extract, ${ }^{5}$ geranium leaf aqueous extract, ${ }^{6}$ Sapium sebiferum leaf extract, ${ }^{7}$ and Thymus kotschyanus extract. ${ }^{8}$ However, these plant extracts contain many different components. These components of each plant extract are different because of different growth stages and conditions for plants, which leads to different reducing power and stabilizing ability for plant extracts. Thus, it may be difficult to precisely control the size and morphology of metal nanoparticles. Specific component of plant extracts has fixed composition. Polyphenols in the plant extracts have highest levels of antioxidant properties. ${ }^{9}$ Polyphenols should be the main component to produce metal nanoparticle. ${ }^{9,10} \mathrm{Fu}$ and coworkers found that the size distribution of proanthocyanidinfunctionalized gold nanoparticles was smaller than that of gold nanoparticles prepared using water extract. ${ }^{11}$ Compared with polyphenols, polysaccharides have mild antioxidant properties and high stability in water. Lentinan (LNT) is soluble and biologically active biomacromolecule. LNT has potential immune regulation, anti-viral and anti-cancer bioactivities. ${ }^{12}$ LNT is composed of one $\beta$-( $1 \rightarrow 6)$-D-glucopyranoside branches for every three $\beta$-( $1 \rightarrow 3)$-glucopyranoside linear linkages. ${ }^{12}$ LNT was used to prepare silver nanoparticles and investigated their antibacterial activity. ${ }^{13}$

Palladium nanoparticles (Pd NPs) have been widely used in various catalytic processes. Herein, it is the first time that a green method to prepare LNT stabilized palladium nanoparticles $\left(\mathrm{Pd}_{n}\right.$-LNT NPs) was demonstrated. Pd $_{n}$-LNT NPs had small size for Pd NPs and high stability in different solutions. The catalytic activity of $\mathrm{Pd}_{n}$-LNT NPs was evaluated by the catalytic reduction of 4-nitrophenol (4-NP). Moreover, the 
biocompatibility of $\mathrm{Pd}_{n}$-LNT NPs was measured by MTT method. The antioxidant property of $\mathrm{Pd}_{n}$-LNT NPs was evaluated by the DPPH free radical scavenging activity assay.

\section{Results and discussion}

\subsection{UV-Vis spectra analysis}

LNT had good antioxidant activity reported by $\mathrm{Tu}$ and coworkers, ${ }^{\mathbf{1 4}}$ leading to their potential ability to reduce the $\mathrm{Na}_{2} \mathrm{PdCl}_{4}$. To evaluate the formation of Pd NPs, the UV-Vis spectra and pictures of forming solution were studied. Fig. 1a showed that $\mathrm{Na}_{2} \mathrm{PdCl}_{4}$ had an obvious peak at $415 \mathrm{~nm}$. After the incubation of $\mathrm{Na}_{2} \mathrm{PdCl}_{4}$ with LNT at $50{ }^{\circ} \mathrm{C}$ for $6 \mathrm{~h}$, the peak of $\mathrm{Na}_{2} \mathrm{PdCl}_{4}$ at $415 \mathrm{~nm}$ disappeared, and a very broad peak was observed. In addition, as the molar ratio of $\mathrm{Na}_{2} \mathrm{PdCl}_{4}$ to LNT increased, the absorbance was bigger and the color of the solution (Fig. 1b) gradually deepened. This was due to the increased content of $\mathrm{Pd}$ elements in solution when the concentration of LNT was $1.82 \mu \mathrm{M}$. The results were consistent with zwitterionic dendrimer-encapsulated Pd NPs ${ }^{15}$ and Pd NPs prepared using Dioscorea bulbifera tuber extract ${ }^{16}$ in previous reports. Both results demonstrated the successful formation of Pd NPs.

\subsection{TEM observation}

The size and dispersion of Pd NPs inside of $\mathrm{Pd}_{n}$-LNT NPs were detected by TEM. As shown in Fig. 2, TEM image indicated that Pd NPs had a nearly spherical shape with highly dispersed states. The sizes of Pd NPs inside of $\mathrm{Pd}_{150}$-LNT NPs, $\mathrm{Pd}_{200}$-LNT NPs, $\mathrm{Pd}_{250}$-LNT NPs were $2.35 \pm 0.57,2.90 \pm 0.69,3.32 \pm$ $0.83 \mathrm{~nm}$, respectively. Thus, Pd NPs inside of $\mathrm{Pd}_{n}$-LNT NPs had small size with narrow size distribution. The sizes of Pd NPs inside of $\mathrm{Pd}_{150}$-LNT NPs was smaller than Pd NPs (12.85 nm) prepared using fritillaria imperialis flower extract by Veisi and coworkers, ${ }^{17}$ indicating that $\mathrm{Pd}_{n}$-LNT had larger specific surface area, which often led to higher catalytic activity.

\subsection{FTIR spectra analysis}

LNT and $\mathrm{Pd}_{150}$-LNT NPs were further characterized by FTIR spectra. ${ }^{18}$ Fig. 3 showed there were five obvious peaks (575, 1031, 1646, 2921 and $3461 \mathrm{~cm}^{-1}$ ) in the FTIR spectra of LNT and $\mathrm{Pd}_{150}$-LNT NPs. The peak at $3461 \mathrm{~cm}^{-1}$ was due to the stretching vibration absorption peak of $\mathrm{O}-\mathrm{H}$. The peak at $2921 \mathrm{~cm}^{-1}$ was
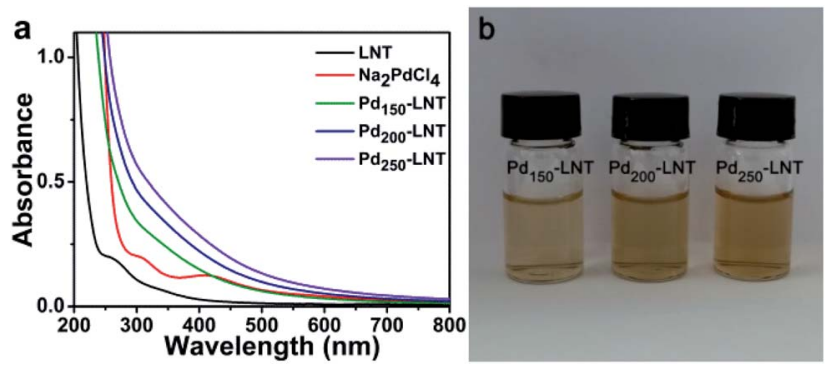

Fig. 1 (a) UV-Vis spectra and (b) pictures of $P_{n}-L N T$ NPs.
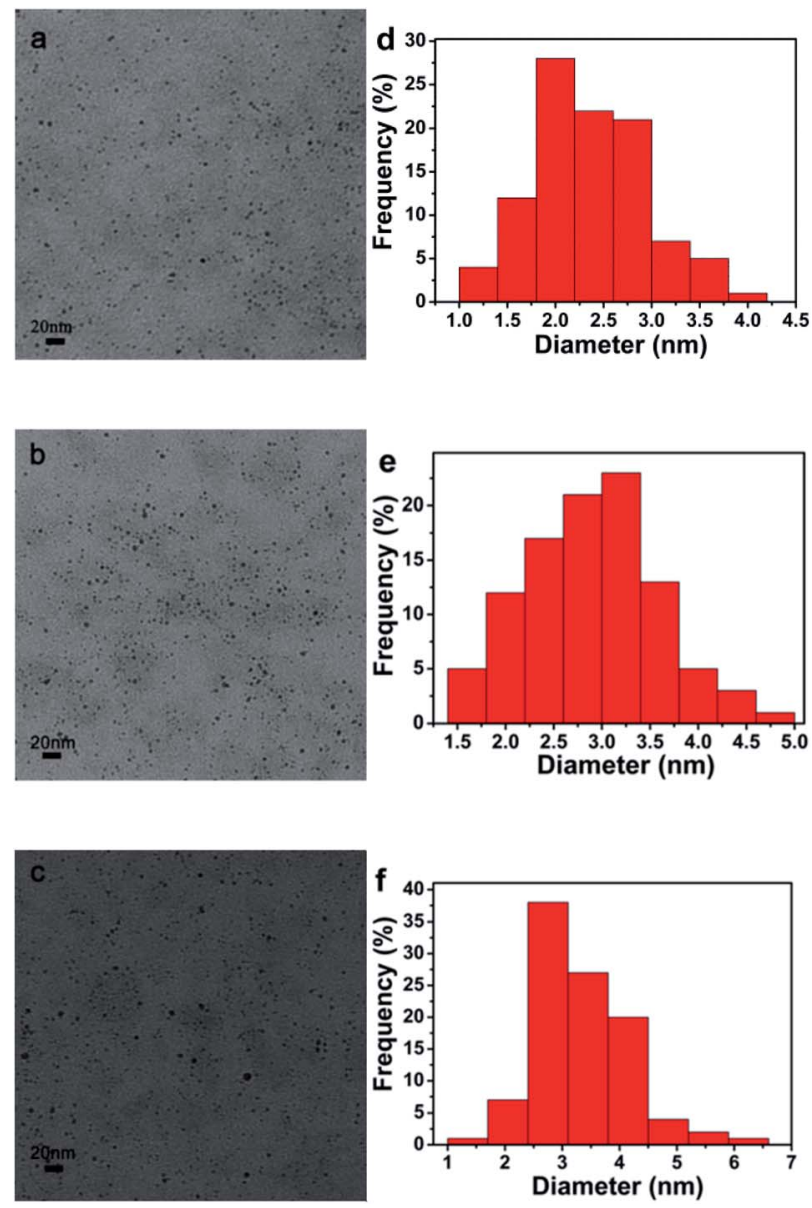

Fig. $2(a-c)$ TEM image and $(d-f)$ corresponding size distributions.

attributed to the stretching vibration absorption peak of $\mathrm{C}-\mathrm{H}$ bond. The characteristic of carbonyl stretching was at $1646 \mathrm{~cm}^{-1} .1031 \mathrm{~cm}^{-1}$ was assigned to the stretching vibration absorption peak of $\mathrm{C}-\mathrm{O}-\mathrm{C}$ on the sugar ring. The absorption peak at $575 \mathrm{~cm}^{-1}$ was attributed to $\beta$-pyranose in the sugar. ${ }^{19}$ There was slight difference between LNT and $\mathrm{Pd}_{150}$-LNT NPs, indicating that the structure of LNT was stable.

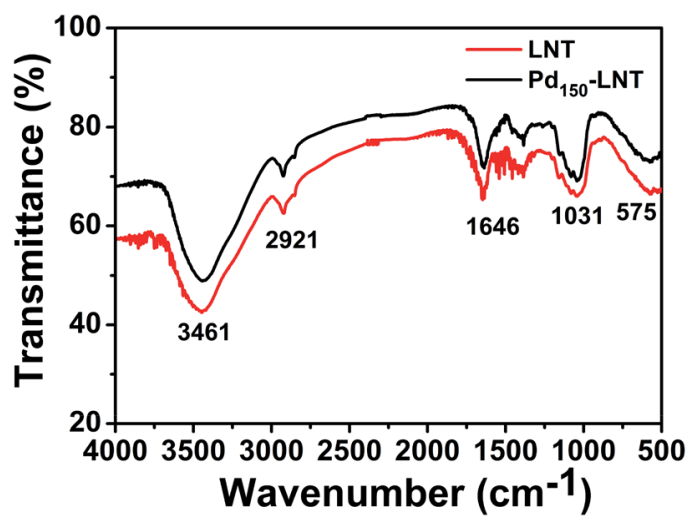

Fig. 3 FTIR spectra of LNT and $\mathrm{Pd}_{150}-\mathrm{LNT}$. 

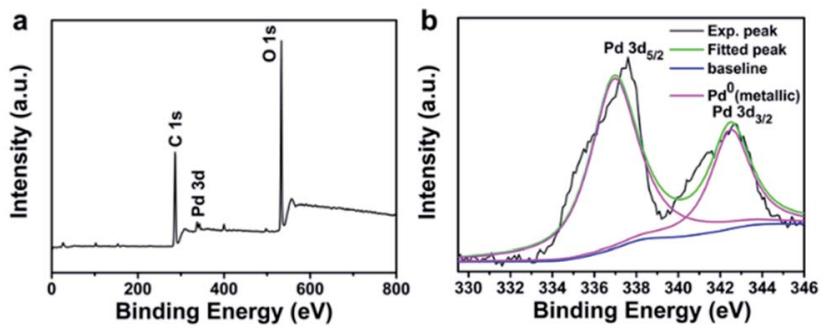

Fig. 4 (a) XPS survey spectrum of $\mathrm{Pd}_{150}$-LNT NPs and (b) the binding energy of $P d 3 d$.

\subsection{XPS analysis}

Elemental composition of $\mathrm{Pd}_{150}$-LNT NPs measured by XPS was used to further study the formation of $\mathrm{Pd}_{n}$-LNT NPs. Fig. $4 \mathrm{a}$ showed that the peaks at 284.6 and $531.36 \mathrm{eV}$ were assigned to $\mathrm{C}$ $1 \mathrm{~s}$ and $\mathrm{O} 1 \mathrm{~s}$, respectively. Both elements were derived from LNT. Fig. 4 b showed the Pd binding energy of $\mathrm{Pd}_{n}$-LNT NPs had two obvious peaks at 342.5 and $337.2 \mathrm{eV}$, which corresponded to $\operatorname{Pd} 3 d_{3 / 2}$ and $P d 3 d_{5 / 2}$, respectively. These values were consistent with $\operatorname{Pd}(0)$ binding energy, indicating that $\operatorname{Pd}(\mathrm{II})$ has been successfully reduced to $\operatorname{Pd}(0)$ by LNT. $^{20}$ Kardanpour and coworkers prepared highly dispersed Pd NPs which had similar binding energy compared with $\mathrm{Pd}_{150}$-LNT NPs. ${ }^{21}$ Therefore, XPS results confirmed the successful preparation of $\mathrm{Pd}_{n}$-LNT NPs.

\subsection{Stability}

Besides the size of Pd NPs, the states of $\mathrm{Pd}_{n}$-LNT NPs in solution were related to their catalytic performance. The hydrodynamic size and zeta potential of $\mathrm{Pd}_{n}$-LNT NPs were determined by DLS. Fig. 5a showed that the hydrodynamic size of LNT was about $20 \mathrm{~nm}$, and the hydrodynamic size of $\mathrm{Pd}_{n}$-LNT NPs was 25, 27, $29 \mathrm{~nm}(n=150,200,250)$, respectively. The hydrodynamic size of $\mathrm{Pd}_{n}$-LNT NPs was about 10 times larger than that measured

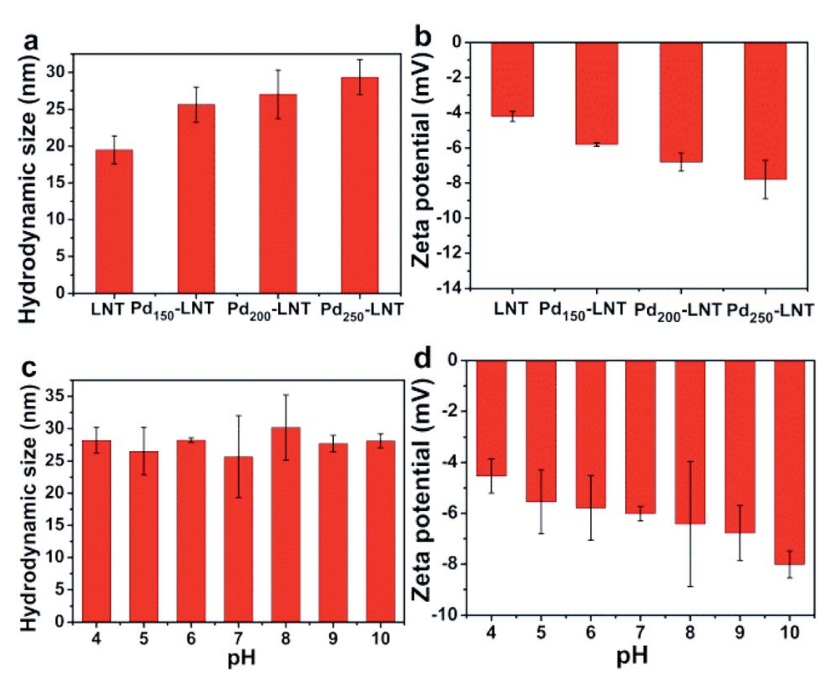

Fig. 5 (a) Hydrodynamic size and (b) zeta potential of $\mathrm{Pd}_{n}$-LNT NPs. (c) The stability and (d) zeta potential of $\mathrm{Pd}_{150}$-LNT NPs with $\mathrm{pH}$ from 4 to 10 within 7 days. by TEM. The difference was due to the different methods of sample preparation. The sample tested by TEM was in a dry state, while the sample measured by DLS was in the hydrated state. Thus, Pd NPs are surrounded by LNT in the hydrated state. Fig. 5b showed the zeta potential of LNT was $-4 \mathrm{mV}$, and the zeta potential of $\operatorname{Pd}_{n}$-LNT NPs was $-6,-7,-8 \mathrm{mV}(n=150$, 200,250 ), respectively. Fig. $5 \mathrm{c}$ showed that the hydrodynamic size of $\mathrm{Pd}_{150}$-LNT NPs was between $25-30 \mathrm{~nm}$ from $\mathrm{pH} 4$ to 10 for 7 days, indicating they maintained good stability in a wide $\mathrm{pH}$ range for 7 days. Fig. $5 \mathrm{~d}$ showed the zeta potential of $\mathrm{Pd}_{150^{-}}$ LNT NPs in different $\mathrm{pH}$ buffers was between -4 and $-8 \mathrm{mV}$. The zeta potential is an important parameter which can be used to assess the stability of nanoparticles. ${ }^{22}$ The zeta potential of nanoparticles is above $+30 \mathrm{mV}$ which results in good stability of nanoparticles. Moreover, the metal nanoparticles can be stabilized by macromolecules such as dendrimer to inhibit agglomeration of nanoparticles due to steric effects. ${ }^{23,24}$ In our case, LNT was used both as a reducing and stabilizing agent to prepare $\mathrm{Pd}_{n}$-LNT NPs. Therefore, electrostatic repulsion and steric hindrance between $\mathrm{Pd}_{150}$-LNT NPs should be main reasons for their high stability. The high stability of $\mathrm{Pd}_{n}$-LNT NPs was good for efficient degradation of organic pollutants in complex environments.

\subsection{Catalytic performance}

Metal nanoparticles have been wildly used in treatment of various organic pollutants. ${ }^{25-27}$ As discussed above, the prepared $\mathrm{Pd}_{n}$-LNT NPs had good stability and large specific surface area. These advantages are beneficial to high catalytic efficiency. $\mathrm{Pd}_{150}$-LNT NPs were used to study the catalytic performance on 4-NP. 4-NP is common organic pollutants and is usually found in insecticides and synthetic dyes. ${ }^{28} 4$-Aminophenol (4-AP) is widely used as a developer, lubricant and dye. $^{29}$ Therefore, the conversion of 4-NP to 4-AP has good value. Fig. 6a showed 4-NP solution had an absorption peak at $317 \mathrm{~nm}$, and this peak shifted to $400 \mathrm{~nm}$ after addition of $\mathrm{NaBH}_{4}$, which corresponded to newly generated 4-hydroxyaminophenol $(4-\mathrm{Hx}) \cdot{ }^{30}$ After the addition of the $\mathrm{Pd}_{150}$-LNT NPs, Fig. 6b showed the peak at $400 \mathrm{~nm}$ quickly decreased and the peak of 4 -AP at $300 \mathrm{~nm}$ increased, which indicated the formation of 4-AP. Fig. 6c showed that the relationship between $\ln \left(C_{t} / C_{0}\right)$ of $\mathrm{Pd}_{150}$-LNT NPs and reaction time was linear. Thus, when $\mathrm{NaBH}_{4}$ was excessive, this catalytic reaction followed pseudo first-order kinetic equation (eqn (1)). ${ }^{31}$ After $21 \mathrm{~min}$, the conversion of 4 -NP was $90 \%$ (Fig. 6d), and the color of the reaction system changed from yellow to colorless. These indicated that $\mathrm{Pd}_{150}$-LNT NPs had good catalytic properties towards the reduction of 4-NP. Fig. $6 \mathrm{f}$ showed that the $k_{\text {app }}$ of the catalytic reaction gradually increased as the increased concentration of Pd NPs which offered more active sites. The catalytic reduction of $4-\mathrm{NP}$ by $\mathrm{Pd}_{150}$-LNT NPs should follow the Langmuir-Hinshelwood kinetic model. ${ }^{32-34} 4-\mathrm{Hx}$ and $\mathrm{BH}_{4}{ }^{-}$were first adsorbed onto the surface of the Pd NPs. The 4-Hx was converted to 4-AP and the product 4-AP left the catalyst surface. Therefore, the active sites provided on the surface of the catalyst were the key factors affecting the catalytic reaction. 
a
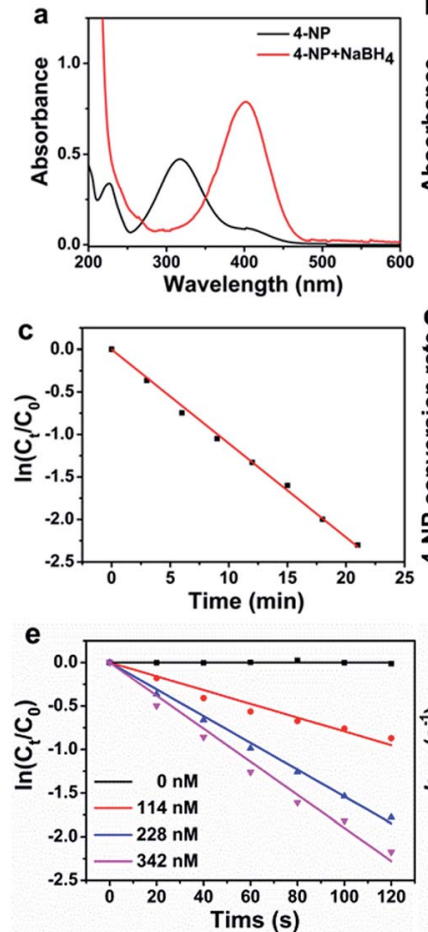
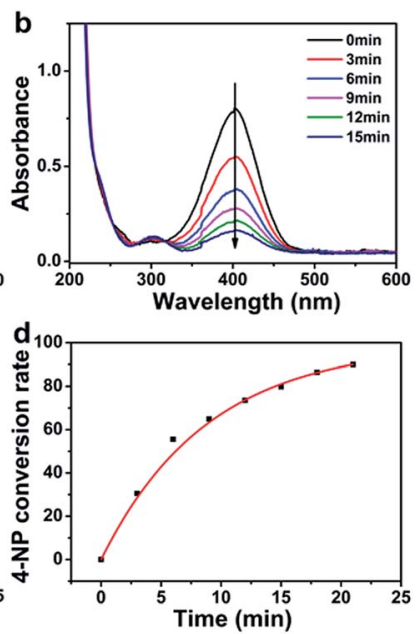

Fig. 6 (a) The UV-Vis spectra of 4-NP and 4-NP $+\mathrm{NaBH}_{4}$. (b) The UVVis spectra of 4-NP $+\mathrm{NaBH}_{4}$ after addition of $\mathrm{Pd}_{150}$-LNT NPs every 3 min and corresponding (c) catalytic kinetics and (d) 4-NP conversion rate. (e) The relationship between $\ln \left(C_{t} / C_{0}\right)$ and the reaction time and (f) the relationship between $k_{\mathrm{app}}$ and concentration of $\mathrm{Pd}_{150}-$ LNT NPs.

$$
\ln \frac{C_{\mathrm{t}}}{C_{0}}=\ln \frac{A_{\mathrm{t}}}{A_{0}}=-k_{\mathrm{app}} t
$$

In order to compare the catalytic performance of $\mathrm{Pd}_{150}$-LNT NPs with other catalysts, normalized rate constant $\left(k_{\text {nor }}=k_{\text {app }}\right)$ $\left.C_{\mathrm{Pd}}\right)^{35}$ and turn over frequency (TOF) ${ }^{36}$ were calculated. The $k_{\text {nor }}$ and TOF of $\mathrm{Pd}_{150}$-LNT NPs were $69.39 \mathrm{~s}^{-1} \mathrm{mM}^{-1}$ and $678.18 \mathrm{~h}^{-1}$, respectively. Table 1 showed the comparison of $\mathrm{Pd}_{150}$-LNT NPs with other catalysts. $\mathrm{Pd}_{150}$-LNT NPs had the highest $k_{\text {nor }}$ and TOF, indicating they had the highest catalytic activity. Morère and coworkers deposited Pd on mesoporous silica which had the $k_{\text {nor }}$ and TOF for $0.188 \mathrm{~s}^{-1} \mathrm{mM}^{-1}$ and $19.08 \mathrm{~h}^{-1}$, respectively. Zhao and coworkers prepared Pd NPs loaded on carbon nanospheres which had the $k_{\text {nor }}$ and TOF for $1.4 \mathrm{~s}^{-1} \mathrm{mM}^{-1}$ and
$504 \mathrm{~h}^{-1}$, respectively. Their catalytic parameters were lower than those of $\mathrm{Pd}_{150}$-LNT NPs. The high catalytic activity of $\mathrm{Pd}_{150}-\mathrm{LNT}$ NPs should be due to their small particle size of $2.35 \pm 0.57 \mathrm{~nm}$ and the corresponding big specific surface area. More importantly, $\mathrm{Pd}_{150}$-LNT NPs remained stable in aqueous solutions in a $\mathrm{pH}$ range of $4-10$. This high stability and high specific surface area provided more exposed Pd atoms which acted as active sites during catalytic reduction of 4-NP.

\subsection{DPPH free radical scavenging assay}

Besides the catalytic activity of $\mathrm{Pd}_{150}$-LNT NPs, the antioxidant activity of $\mathrm{Pd}_{150}$-LNT NPs and $\mathrm{Pd}_{250}$-LNT NPs were also measured. DPPH was a stable free radical compound and was employed to evaluate the antioxidant activity. Antioxidant activity plays an important role in the protection of our body from harm of free radical. ${ }^{43,44}$ Fig. 7 showed that when the concentration of $\mathrm{Pd}_{150}$-LNT NPs increased from 0.27 to $1.33 \mathrm{mg}$ $\mathrm{mL}^{-1}$, the antioxidant activity increased from $20 \%$ to $60 \%$, indicating effective free radical inhibition by $\mathrm{Pd}_{150}$-LNT NPs. Thus, $\mathrm{Pd}_{150}$-LNT NPs and $\mathrm{Pd}_{250}$-LNT NPs had obvious antioxidant activity. Dimocarpus longan seed extract was also used as a reducing and stabilizing agent to prepare silver nanoparticles which had good antioxidant activity. ${ }^{45}$

\subsection{Biocompatibility}

The presence of microorganisms in sewage has a significant reverse effect on the catalytic degradation of organic pollutants, which should be due to strong interaction between catalysts and

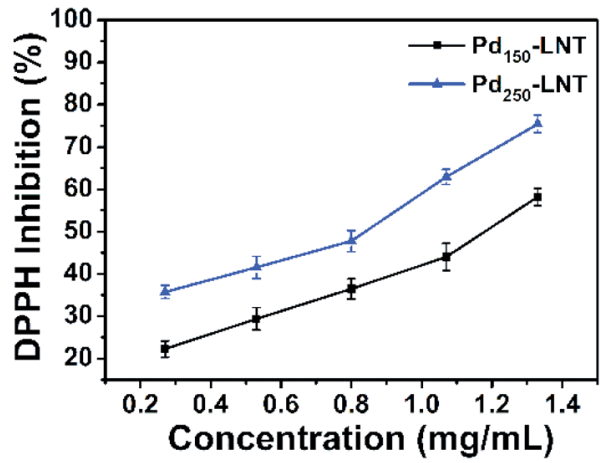

Fig. 7 DPPH free radical scavenging activity of $\mathrm{Pd}_{150}$-LNT NPs and $\mathrm{Pd}_{250}$-LNT NPs.

Table 1 Comparison of $k_{\text {nor }}$ and TOF of $\mathrm{Pd}_{150}-\mathrm{LNT}$ NPs with other catalysts

\begin{tabular}{|c|c|c|c|c|}
\hline Catalyst & Pd size (nm) & $k_{\text {nor }}\left(\mathrm{s}^{-1} \mathrm{mM}^{-1}\right)$ & $\operatorname{TOF}\left(\mathrm{h}^{-1}\right)$ & Ref. \\
\hline Pd/SBA15 & $\sim 7$ & 0.188 & 19.08 & 37 \\
\hline Pd/SPB-PS & 2.4 & 12.0 & 820.8 & 38 \\
\hline $\mathrm{Pd} / \mathrm{Al}_{2} \mathrm{O}_{3}$ & $>5.8$ & 1.085 & - & 40 \\
\hline $\mathrm{Pd} / \mathrm{PiHP}$ & 2.1 & - & 379 & 41 \\
\hline Pd/oMWCNT & 2.2 & - & 252 & 42 \\
\hline
\end{tabular}



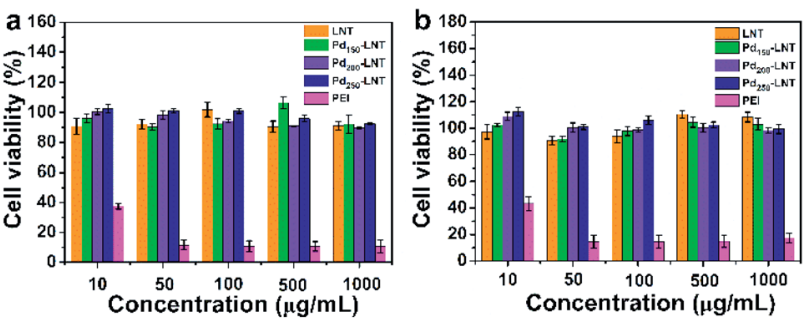

Fig. 8 Cell viabilities of (a) A549 cells and (b) HCT116 cells for $\mathrm{Pd}_{n}$-LNT NPs $(n=150,200,250)$ and LNT.

microorganisms. This interaction always results in high cytotoxicity of nanoparticles. ${ }^{46}$ Here, the cytotoxicity of $\mathrm{Pd}_{n}$-LNT NPs ( $n=150,200$ and 250) was determined by MTT assay on A549 cells and HCT116 cells. MTT is commonly used method to evaluate the cytotoxicity of nanoparticles. ${ }^{47-49}$ As illustrated in Fig. 8, the cell viability was higher than $90 \%$ after incubation with $\mathrm{Pd}_{n}$-LNT NPs and LNT at a concentration within $1000 \mu \mathrm{g}$ $\mathrm{mL}^{-1}$. Both $\mathrm{Pd}_{n}$-LNT NPs and LNT had good biocompatibility. In contrast, polyethyleneimine (PEI) had high cytotoxicity because of highly positive charges on their surface. Taken together, $\mathrm{Pd}_{n}$-LNT NPs had good biocompatibility in vitro. This should be due to biocompatible LNT and the negative surface charge of $\mathrm{Pd}_{n}$-LNT NPs. Both factors were good for reduced the interaction between $\mathrm{Pd}_{n}$-LNT NPs and cells. The high biocompatibility of $\mathrm{Pd}_{n}$-LNT NPs was good for bio-related catalytic applications in nature.

\section{Conclusion}

In summary, we have prepared $\mathrm{Pd}_{n}$-LNT NPs, where LNT was used both as a reducing and stabilizing agent. This method was simple, eco-friendly and easy to scaled up. Compared with plants extracts, LNT had fixed components and weaker reducing ability. $\mathrm{Pd}_{n}$-LNT NPs had nearly spherical shape for Pd NPs and showed high stability in a wide $\mathrm{pH}$ range for 7 days. $\mathrm{Pd}_{n}$-LNT NPs had the hydrodynamic size about 25-29 $\mathrm{nm}$ and slightly negative zeta potential. In addition, $\operatorname{Pd}_{n}-\mathrm{LNT}$ NPs had high catalytic activity for 4-NP to generate 4-AP due to the high specific surface area and stability. Furthermore, $\mathrm{Pd}_{n}$-LNT NPs showed no cytotoxicity towards cells and good antioxidant activity. $\mathrm{Pd}_{n}$-LNT NPs have great potential application in biorelated catalysis and nanomedicine.

\section{Conflicts of interest}

There are no conflicts of interest to declare.

\section{Acknowledgements}

The authors appreciate financial support from National Nature Science Foundation of China (21474085, 21674092 and 21975216), and National Development Project on Key Basic Research (973 Project, 2015CB655303), Natural Science Foundation of Hebei Province (B2017203229), China Postdoctoral Science Foundation (2016M601284).

\section{Notes and references}

1 N. Tsumori, L. Chen, Q. Wang, Q.-L. Zhu, M. Kitta and Q. Xu, Chem, 2018, 4, 845-856.

2 C. Wang, Y. Shi, Y.-Y. Dan, X.-G. Nie, J. Li and X.-H. Xia, Chem.-Eur. J., 2017, 23, 6717-6723.

3 J. Prasad Rao, P. Gruenberg and K. E. Geckeler, Prog. Polym. Sci., 2015, 40, 138-147.

4 F. K. Alsammarraie, W. Wang, P. Zhou, A. Mustapha and M. Lin, Colloids Surf., B, 2018, 171, 398-405.

5 B. Şahin, A. Aygün, H. Gündüz, K. Şahin, E. Demir, S. Akocak and F. Şen, Colloids Surf., B, 2018, 163, 119-124.

6 R. D. Rivera-Rangel, M. P. González-Muñoz, M. AvilaRodriguez, T. A. Razo-Lazcano and C. Solans, Colloids Surf., A, 2018, 536, 60-67.

7 K. Tahir, S. Nazir, B. Li, A. Ahmad, T. Nasir, A. U. Khan, S. A. A. Shah, Z. U. H. Khan, G. Yasin and M. U. Hameed, J. Photochem. Photobiol., B, 2016, 164, 164-173.

8 M. Hamelian, M. M. Zangeneh, A. Amisama, K. Varmira and H. Veisi, Appl. Organomet. Chem., 2018, 32, 4458.

9 F. U. Khan, Y. Chen, N. U. Khan, Z. U. H. Khan, A. U. Khan, A. Ahmad, K. Tahir, L. Wang, M. R. Khan and P. Wan, J. Photochem. Photobiol., B, 2016, 164, 344-351.

10 S. Lebaschi, M. Hekmati and H. Veisi, J. Colloid Interface Sci., 2017, 485, 223-231.

11 L. Biao, S. Tan, Q. Meng, J. Gao, X. Zhang, Z. Liu and Y. Fu, Nanomaterials, 2018, 8, 53.

12 Y. Zhang, S. Li, X. Wang, L. Zhang and P. C. K. Cheung, Food Hydrocolloids, 2011, 25, 196-206.

13 D. Guo, G. Liu, X. Li, X. Tang, J. Zhang, X. Zhu and S. Jiang, J. Bionanosci., 2015, 9, 325-329.

14 X. Huang, Z. Tu, Y. Jiang, H. Xiao, Q. Zhang and H. Wang, Int. J. Biol. Macromol., 2012, 51, 926-932.

15 L. Wang, J. Zhang, X. Guo, S. Chen, Y. Cui, Q. Yu, L. Yang, H. Sun, D. Gao and D. Xie, New J. Chem., 2018, 42, 1974019748.

16 S. Ghosh, R. Nitnavare, A. Dewle, G. B. Tomar, R. Chippalkatti, P. More, R. Kitture, S. Kale, J. Bellare and B. A. Chopade, Int. J. Nanomed., 2015, 10, 7477-7490.

17 M. Yazdankhah, H. Veisi and S. Hemmati, J. Taiwan Inst. Chem. Eng., 2018, 91, 38-46.

18 K. Ma, R. Wang, T. Jiao, J. Zhou, L. Zhang, J. Li, Z. Bai and Q. Peng, Colloids Surf., A, 2020, 584, 124023.

19 Z. Ruan, J. Su, H. Dai and M. Wu, Int. Immunopharmacol., 2005, 5, 811-820.

20 Y. Zhao, J. Feng, L. Hong, Y. Li, C. Wang and S. Ye, Inorg. Chem. Front., 2018, 5, 1133-1138.

21 R. Kardanpour, S. Tangestaninejad, V. Mirkhani, M. Moghadam, I. Mohammadpoor-Baltork, A. R. Khosropour and F. Zadehahmadi, J. Organomet. Chem., 2014, 761, 127-133.

22 D. Silvestri, S. Wacławek, B. Sobel, R. Torres-Mendieta, V. Novotný, N. H. A. Nguyen, A. Ševců, V. V. T. Padil, J. Müllerová, M. Stuchlík, M. P. Papini, M. Černík and R. S. Varma, Green Chem., 2018, 20, 4975-4982.

23 R. M. Crooks, M. Zhao, L. Sun, V. Chechik and L. K. Yeung, Acc. Chem. Res., 2001, 34, 181-190. 
24 H. Sun, F. M. Haque, Y. Zhang, A. Commisso, M. A. Mohamed, M. Tsianou, H. Cui, S. M. Grayson and C. Cheng, Angew. Chem., Int. Ed., 2019, 58, 10572-10576.

25 R. El-Shabasy, N. Yosri, H. El-Seedi, K. Shoueir and M. ElKemary, Optik, 2019, 192, 162943.

26 D. Yang, R. Zhang, T. Zhao, T. Sun, X. Chu, S. Liu, E. Tang and X. Xu, Catal. Sci. Technol., 2019, 9, 6145-6151.

27 Y. Cui, B. Liang, J. Zhang, R. Wang, H. Sun, L. Wang and D. Gao, Transition Met. Chem., 2019, 44, 655-662.

28 W. Shen, Y. Qu, X. Pei, S. Li, S. You, J. Wang, Z. Zhang and J. Zhou, J. Hazard. Mater., 2017, 321, 299-306.

29 M. Guo, J. He, Y. Li, S. Ma and X. Sun, J. Hazard. Mater., 2016, 310, 89-97.

30 S. Gu, J. Kaiser, G. Marzun, A. Ott, Y. Lu, M. Ballauff, A. Zaccone, S. Barcikowski and P. Wagener, Catal. Lett., 2015, 145, 1105-1112.

31 X. Guo, J. Zhang, Y. Cui, S. Chen, H. Sun, Q. Yang, G. Ma, L. Wang and J. Kang, New J. Chem., 2019, 43, 7646-7652.

32 H. Cheng, X. Qian, Y. Kuwahara, K. Mori and H. Yamashita, Adv. Mater., 2015, 27, 4616-4621.

33 R. Begum, Z. H. Farooqi, E. Ahmed, K. Naseem, S. Ashraf, A. Sharif and R. Rehan, Appl. Organomet. Chem., 2017, 31, 3563.

34 L. Wang, X. Zhang, Y. Cui, X. Guo, S. Chen, H. Sun, D. Gao, Q. Yang and J. Kang, Transition Met. Chem., 2019, DOI: 10.1007/s11243-019-00353-z.

35 X. Le, Z. Dong, Y. Liu, Z. Jin, T.-D. Huy, M. Le and J. Ma, J. Mater. Chem. A, 2014, 2, 19696-19706.

36 L. Wang, Q. Yang, Y. Cui, D. Gao, J. Kang, H. Sun, L. Zhu and S. Chen, New J. Chem., 2017, 41, 8399-8406.
37 J. Morère, M. J. Tenorio, M. J. Torralvo, C. Pando, J. A. R. Renuncio and A. Cabañas, J. Supercrit. Fluids, 2011, 56, 213-222.

38 M. Yu, L. Yan, P. Frank and B. Matthias, Chem. Mater., 2007, 19, 1062-1069.

39 Z. Zhao, X. Ma, X. Wang, Y. Ma, C. Liu, H. Hang, Y. Zhang, Y. Du and W. Ye, Appl. Surf. Sci., 2018, 457, 1009-1017.

40 S. Arora, P. Kapoor and M. L. Singla, React. Kinet., Mech. Catal., 2010, 99, 157-165.

41 H. Li, L. Han, J. Cooper-White and I. Kim, Green Chem., 2012, 14, 586-591.

42 H. He and C. Gao, Molecules, 2010, 15, 4679-4694.

43 M. Hamelian, K. Varmira and H. Veisi, J. Photochem. Photobiol., B, 2018, 184, 71-79.

44 D. Dong, Q. Li, W. Hou and H. Zhang, J. Mol. Struct., 2020, 1199, 127002.

45 F. U. Khan, Y. Chen, N. U. Khan, Z. U. H. Khan, A. U. Khan, A. Ahmad, K. Tahir, L. Wang, M. R. Khan and P. Wan, J. Photochem. Photobiol., B, 2016, 164, 344-351.

46 Y. Cui, J. Zhang, Q. Yu, X. Guo, S. Chen, H. Sun, S. Liu, L. Wang, X. Lai and D. Gao, New J. Chem., 2019, 43, 90769083.

47 X. W. Zhang, L. Y. Luo, L. Li, Y. C. He, W. W. Cao, H. Liu, K. Niu and D. W. Gao, Nanomedicine, 2019, 15, 142-152.

48 L. Luo, Y. Bian, Y. Liu, X. Zhang, M. Wang, S. Xing, L. Li and D. Gao, Small, 2016, 12, 4103-4112.

49 Y. He, C. Cong, Y. He, Z. Hao, C. Li, S. Wang, Q. Zhao, H. He, R. Zhu, X. Li and D. Gao, Chem. Eng. J., 2019, 375, 122079. 